\section{GEOGRAPHICAL NOTES.}

AT the Koyal Geographical Scciety on Monday night, a paper was read by Mr. F. S. Arnot on his journey from Natal to Bihé and Benguella, and thence across the central plateau of Africa to the sources of the Zambesi and the Congo. Mr. Arnot reached Natil in September $\mathrm{I} 88 \mathrm{I}$, and has only just returned from his seven years' wanderings, during which he crossed the continent to some extent in the route of Livingstone. His paper forms an important supplement to the work of Livingstone, Cameron, Ivens and (apello, and the German traveller Reichart. Crosing from Natal obliquely, he struck the Zambesi near Sesheke, and ascended the river to Lealui, the town of Liwanika, to endeavour to persuade the chief to let him proceed northwards among the Batonge and Mashashe. Unsuccessful in this, Mr. Arnot left Lealui in May 1884, and proceeded to Bihe and the coast. Returning to Bihé, Mr. Arnot proceeded eastwards, crossing the interesting country from which so many rivers take their rise, flowing north, south, and west, to the Congo, the Zambesi, and the Atlantic. He touched Lake Dilolo, which he has reduced to very small dimensions, and has done something to rectify our knowledge of the sources of the Zambesi. The main stream, according to $\mathrm{Mr}$. Arnot, comes from the east, and of this the Leeka is only a tributary. He stayed for two years at the capital of the kingdom of the chief Msidj, of whom and his government he gives an interesting account. Here he was in the region of the sources of the Lualaba. Msidi, who is really a native of Unyanyembe, seems a man of some ability, and is rapidly extending his power. $\mathrm{He}$ and Kangombe between them have almost swallowed up the once powerful kingdom of Muata Yanvo. Mr. Arnot returns to the Bangweolo region in March next.

Dr. Meyer, and his companion Dr. O. Baumann, who were recently compelled by the hostility of the natives in East Africa to take flight to the coast, actually succeeded in crossing the country of Usambara by a new route. After marching through Bondei to the mission station of Magila, they travelled for several days through a fertile, and in places thickly-wooded depression, which forms part of the Sigi basin, reaching Hanon on September 8. Crossing the Mielo Ridge they descended into the valley of the Kumba. River, and on September is reached the valley of Mlal,, where the Umba River runs. This region is well cultivated, and covered with numerous and large villages. Proceeding to Masende, Dr. Baumann with some natives explored the mountains, arriving eventually at a fertile region inhabited by the Wambunga. These people differ completely from the Washamba of Usambara, and are a remnant of the aborigines of the mountains, speaking a dialect similar to the Kipare.

From the new volume of the Geographische Jahrbuch we learu that there are now ror Geographical Societies in the world. Of these, France and her colonies have more than any other country, -29 , with 19,800 members; next comes Germany, with 22 Societies, and 9200 members; followed by Grea Britain and her colonies with 9 Societies, and 5600 members. There are altogether $\mathrm{r} 30$ gengraphical serials published in the various countries of the world.

M. Jean Chaffanjon, the explorer of the Orinnco, we learn from the Scotiish Geographical Magazine, is about to undertake a new task. He is going to explore the peninsula and lake of Maracaibo. A tribe of Indians live in the peninsula, concerning whom no scientific data have been obtained, for they allow no one to go among them. M. Chaffanjon will try to penetrate this mystery. He will also examine the lacustrine dwellings of an extinct race in the Maracaibo Lake, and then, following the chain of the Andes, will ascend to the source of the Magdalena, cross the group of mountains which separates this river from the Rio Canca, and explore the latter down to Antioquia.

\section{SOME ANNELIDAN AFFINITIES}

\section{IN THE ONTOGENY OF THE VERTEBRATE} NERVOUS SYSTEM.

I $\mathrm{N}$ the controversy respecting the ancestry of the Vertebrata the nervous system has always played an important part: that system is-I think Prof. Wiedersheim was the first to say it - the most aristocratic and conservative of all the organ systems of the animal body, and it clings to ancestral traditions more than any other. Anyone who has read Kleinenberg's marvellous account of the complicated menner in which the permanent nervous apparatus of the Annelid worm is built up from that of the larva (in which process of building up it passes through stages which can only be looked upon as ancestral), will readily agree that if we are ever to trace the ancestry of Vertebrates at all, the nervous system will probably form a significant factor in the solution.

The attempts made hitherto to homologize the nervous system of Vertebrates, either in the embryo or in the adult, with that of some Invertebrate or other, do not appear to have met with much success. To take one of the most recent of these. Prof. Hubrecht has, at the close of his Challenger Report on the Nemertines, indicated what he would regard as points of homology between the nervous system of this group and that of Vertebrates. The com. parison is, in my opinion, exceedingly strained, and indeed it would not be difficult to show that it is absolitely erroneous.

The theory of the descent of Vertebrates from animals allied to the Tunicata was, as is well known, partially based on certain characters of the nervous system in the Tunicate larva; but that theory can now hardly be defended, since Dohrn has adduced powerful argumen's for putting the descent the other way about-i.e. from Vertebrates to Tunicata-by insisting that the structure and development of Tunicata prove them to be degenerate Vertebrates.

As a third alternative we have a descent offered us by Bateson from Balanoglossus-like animals, with gill-clefts and a nervous system and notochord resembling that of Vertebrates. Many zoologists see the main and only resemblance between Balanoglossus and Vertebrates in the possession of gill-clefts. It is many years now since these structures in the two grouns were first com pared, and the supposed relationships between them more recently insisted upon do not seem to me to be of a very stable order. The nervous system and notochord of Balanoglossus are to be excluded from the comparison simply because they are on the hrmal side of the body, and therefore cannot be compared to structures which, like the nervous system and notochord of Verte. brates, are not on the hæmal side. As I am here only considering the claims of the nervous system to an homology, I cannot fully discuss the gill.clefts of Balanoglossus, and need only remark that a respiratory function of some part of the alimentary canal-generally the anterior part-is very commonly met with in many classes of the animal kingdom. Now, gill-clefts alone, without sense-organs, skeleton, nerves, or muscles (and these have not been described yet for Balanoglossus), are merely the results of a gut respiration, the alimentary tract having acquired openings on the lateral surface of the body, and it is by no means improbable that such openings could be acquired independently in two groups of animals otherwise widely separated. Two such groups are Balanoglossus and the Vertebrata.

The only remaining theory ${ }^{1}$ of Vertebrate ancestry demanding consideration is that of Semper and Dohrn, which would derive those animals from Annelid worms. The first comparison concerned the nephridia ; and it is to be remarked that the nervous system, the question of the homology of which has not been left in the background, has alway's been the great obstacle in the way of its acceptation, for no one has, as yet, succeeded in finding, in the Vertebrate, any homologue of the Annelidan supra-œsophageal ganglion. There have been plenty of wild and improbable speculations as to its whereabouts. A new era, however, opens with Kleinenberg's hint that possibly the supra-œsophageal ganglion of Annelids is suppressed even in the ontogeny of Vertebrates; and, if we concede this, we must look to the ventral chain of the Annelids as typifying the initial structure from which the central nervous system of Vertebrates arose. And now what points of agreement have been discovered between these two structures and their related nerves and senseorgans?

Eisig has compared the lateral sense-organs of Capitellidæ, which are segmentally arranged along the whole body of the animal, with the lateral sense-organs of Vertebrates. The latter arise in the head, and are at first confined to the head metameres : later they grow on to the trunk; they there become also segmental, but they are irnervated by a true cranial nerve, Now, although Dr. Eisig's comparison is a very enticing one, it can be neither accepted nor rejected without further inquiry. There are many facts for it and some very important ones which, though not directly opposed to it, are not in its favour. We must attach a good deal of importance to it, for the

'Balfur ("Elasmobranch Fishes," p. I 71) є nunciatcd a different theory which can !:ardly now be maintained. 